\title{
Status of the Polynesian Megapode Megapodius pritchardii on Niuafo'ou (Tonga)
}

\author{
ANN GÖTH and UWE VOGEL
}

\section{Summary}

From October 1991 to January 1993, the Polynesian Megapode or Malau Megapodius pritchardii on the island Niuafo' ou, Kingdom of Tonga, was studied as part of a conservation project. The reproductive population was estimated at 188-235 pairs. Owing to an apparent lack of juveniles, the total population is not expected to be much larger. Compared to previous assessments this estimate gives evidence for a serious decline, but the methodologies used in all estimates differ considerably. However, a decline is also indicated by the fact that two of the 11 communal nesting grounds have been abandoned since 1979, while no new sites have been reported. Additionally, the Malau has disappeared from the vicinity of villages during the last 15 years. On a cat-free and undisturbed islet in the crater lake the density of Malaus is 1.29 pairs per ha. In other areas, where access for humans, dogs and cats was easy, the density of the Malau was only 0.16 pairs per ha. The main reason for the decline is over-harvesting of eggs by the local people. Habitat destruction or degradation are not responsible, and rats and domestic pigs seem to have no negative influence.

\section{Introduction}

The Polynesian Megapode Megapodius pritchardii, or Malau as it is called by the Tongan people, whose range is restricted to a single island, Niuafo'ou, in the north of the Kingdom of Tonga, is the only extant megapode in Polynesia, its nearest congener, the Vanuatu Megapode $M$. layardi, living $1,600 \mathrm{~km}$ to the west in Vanuatu. The Tongan island of Niuafo' ou (15 $\left.36^{\prime} \mathrm{S} 175^{\circ} 38^{\prime} \mathrm{W}\right)$ lies about $400 \mathrm{~km}$ from Vava'u, Tonga, and Savaii, Western Samoa (Figure 1 ). The island is a collapsed volcano (Jaggar 1931), $8 \mathrm{~km}$ in diameter, with a large lake containing three islets in the middle (Figure 2). The lake is surrounded by a ridge up to $200 \mathrm{~m}$ high which is steep on the inner side, and which descends gently into the sea on the outer side. Approximately 760 inhabitants (Anon. 1991) live on the outer slopes, which are mainly covered by plantations and lava fields. At least nine eruptions have occurred during the last 200 years (Richard 1962). Following the last outbreak of lava in 1946, which destroyed the main village, the people were evacuated and were not allowed to return until 1958. Prior to this evacuation around 1,300 people lived on Niuafo'ou (Rogers 1986).

Humid, broad-leaved forest with a dense canopy is found on the inner slopes of the crater and on the islands in the crater lake. In places where eruptions have occurred recently the cinder hills and lava flows are covered with ironwood trees Casuarina littorea. Only some of the broad-leaved trees from the under- 


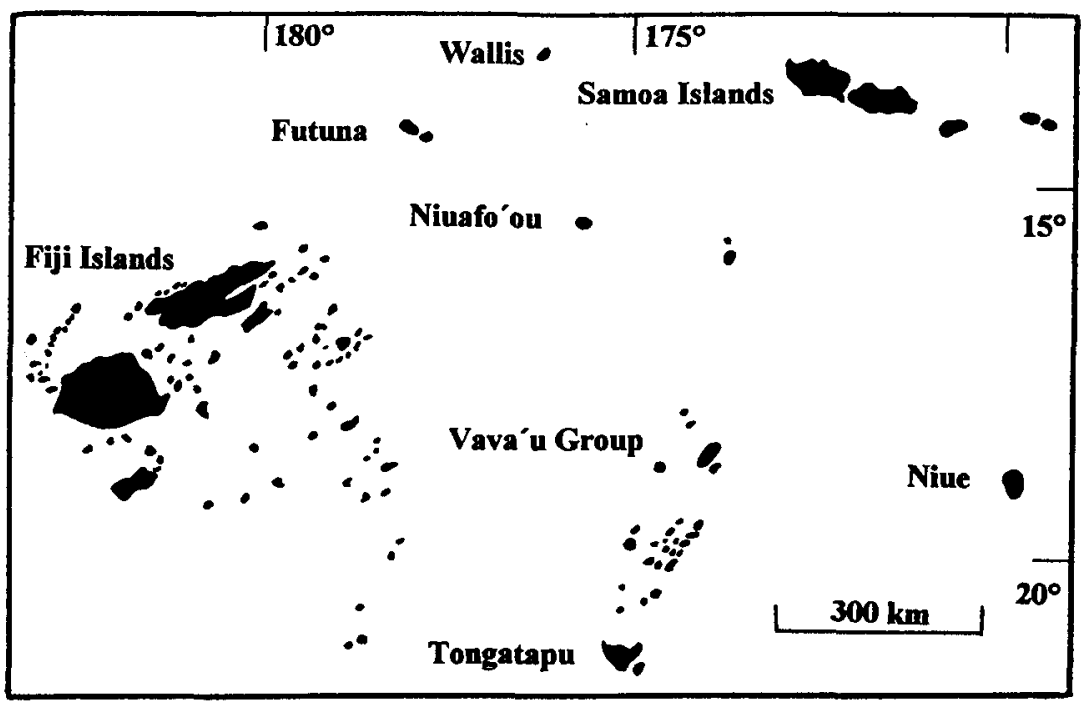

Figure 1. Map showing position of Niuafo' ou Island, Kingdom of Tonga.

storey rise into the canopy. Since many plantations, especially in the remoter parts of the island, are today in a fairly neglected state, all stages of regeneration into secondary forest can be found.

Like the other members of the family Megapodiidae, the Malau does not incubate its eggs with body heat. Instead, it buries them up $1.5 \mathrm{~m}$ deep in volcanically heated soil, in the caldera, near a central crater lake, and in fissures on the outer slope of the island crater. Several such burrows, which are used repeatedly by one or more females, are grouped together in a so-called nesting ground. Nine different nesting grounds were known during the course of our study, which extended earlier research by Weir (1973), Todd (1983) and Rinke (1986, 1991). The Malau is likely to be monogamous and male and female are often seen close together, foraging for invertebrates in damp leaf-litter on the ground. Pairs defend territories throughout the year against intruding pairs or single birds and advertise their presence with duets.

Exact knowledge of the population size of the species was necessary in order to decide and justify protective measures such as translocation to other volcanic islands in Tonga (Göth and Vogel unpublished data).

\section{Methods}

A field survey on Niuafo'ou was carried out from October 1991 to January 1993, except for five short periods of 2-3 weeks, when the observers left the island.

\section{Nesting grounds}

All known nesting grounds of the Malau on Niuafo'ou were mapped and compared with the descriptions given by Todd (1983). Local people were asked about egg-collecting and the locations where eggs could be found nowadays 


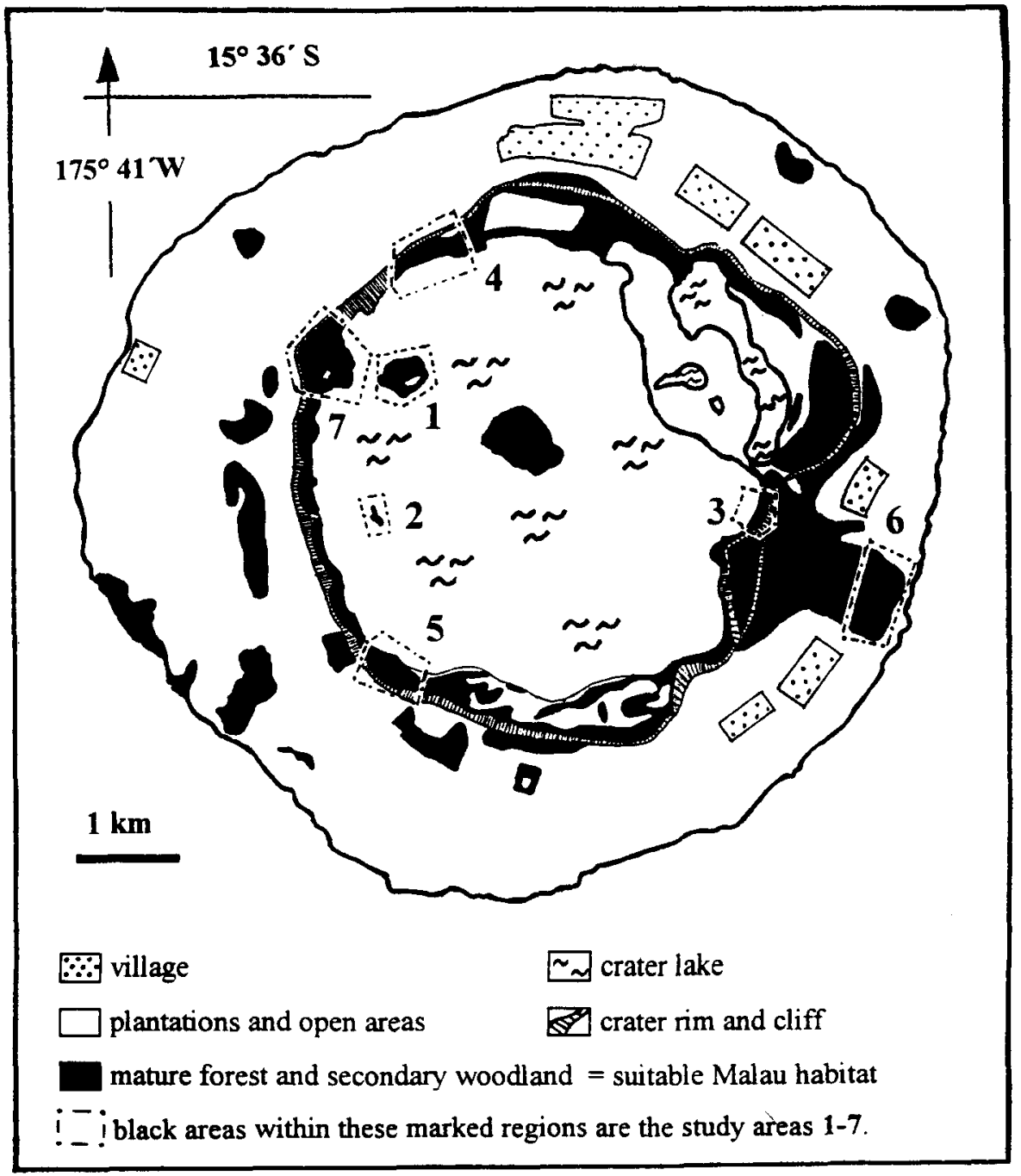

Figure 2. Distribution of the seven study areas on Niuafo'ou.

and in the past. In addition, other parts of the crater wall near the lake were searched for unknown nesting grounds.

\section{Density estimates}

To evaluate the total area on which the megapodes occur all parts of the island were visited regularly and all areas where they could be heard or seen were drawn on a map. On the inner slopes of the island crater the work was mainly undertaken by listening to the birds' calls from a boat on the crater lake.

Owing to lack of time and the inaccessibility of some inner slopes, surveys could not cover the whole island. Birds were therefore counted in seven representative study areas (Figure 2). The size of each area is given in Table 2, and 
Table 1. Allocation of the study areas $(1-7)$ to six different habitat types

\begin{tabular}{llll}
\hline & No predators & Few predators & Many predators \\
$<800 \mathrm{~m}$ to nesting ground & 1 & 3 & 5 \\
$>800 \mathrm{~m}$ to nesting ground & 2 & 4 & $6 \& 7$ \\
\hline
\end{tabular}

together they represent 102.8 ha $(16 \%)$ of the whole area $(641.5$ ha) now inhabited by the birds. The study areas were selected to avoid biases such as edge effects of ridges or clearings. In addition they were chosen according to the criteria:

(1) Accessibility to predators. We assumed that the more predators (feral cats Felis and dogs Canis) frequented a study area, the fewer megapodes would live there. Accordingly each of the study areas was assigned to one of three different classes of predator influence: (a) islets in the crater lake (areas 1 and 2, Figure 2), with no cats and dogs and only very few people hunting ("no predators"); (b) the hills of the inner crater walls, which descended from the crater rim to the lake at an angle of $30-50^{\circ}$, were very seldom visited by people and dogs, because of the almost impassable terrain (areas 3 and 4 ). Nevertheless, cats were seen here regularly ("few predators"); (c) flat areas inside or outside the crater rim were often visited by people and frequented by dogs and cats, because they were located either close to the main paths to the lake (areas 5 and 7), near a plantation (area 7) or adjacent to a village at the outer crater rim (area 6).

(2) Distance to the nearest nesting ground. Since our studies revealed that the females carry a heavy egg most of the year, weighing up to $24 \%$ of their body weight and often making them sluggish and incapable of flight (Göth and Vogel unpublished data), it was assumed that this distance could influence the density of the birds in a given area. Consequently each study area was classified as being located within or beyond $800 \mathrm{~m}$ of a nesting ground.

The combination of these factors, which were assumed to influence the density of the birds, resulted in six different habitat types for the seven study areas (Table 1).

During the counts the presence of megapodes was determined by responses to playback of calls. An observer walked slowly through each test area, stopping every $100 \mathrm{~m}$ when the taped song of a male was played four times followed by a duet (see below) four times. The loudspeaker was mounted one metre above the ground and four metres away from the observer, and each playback was followed by a silent period of five minutes, during which all responses from nearby birds were noted. The positions of all such megapodes heard or seen were mapped and voices were allocated to males or females. Counting between 1 hoo and 14 hoo was avoided, as the megapodes seemed less active then. All surveys were carried out in calm weather to avoid unfavourable conditions for sound transmission. By using this method it was possible to map all pairs, and also unpaired males in their territories. Immature birds never answered the playbacks.

Every study area was visited at least three times. Counts were carried out approximately every 14 days in one of the study areas. From experience with a 
small marked population on one of the islets in the crater lake, which was surveyed from I November 1991 to I October 1992, it was judged that three surveys within a given area were sufficient to determine reliable information about the true number of pairs present there. Since pairs defend their territories all year round and no seasonal peaks in response to playback were found on the islet, it seemed that counts were equally effective at all times of year. Only maximum and minimum numbers of pairs were used for the density estimates.

\section{Results}

\section{Density estimates and population size}

Accessibility to predators influenced the density of the birds in each study area (Figure 3). On the islets in the crater lake, on which the birds were protected from predators by a water barrier, the highest densities were found (areas 1 and 2, Figure 2). In contrast, densities were significantly lower on the steep hills of the inner crater walls (areas 3 and 4) which had been assigned to the class "few predators". Lowest population densities were found in flat areas (5, 6 and 7 ) inside and outside the crater rim, where access for predators was easy.

Amongst the study areas where predators occurred (areas 3-7) the population density was higher in those which were located within $800 \mathrm{~m}$ of a nesting ground (areas 3 and 5) than those farther away (areas 4, 6 and 7) (Figure 4). Only the maximum numbers of pairs recorded in each study area were used for the comparisons.

All areas occupied by Malaus but not included within study areas were classified according to their accessibility to predators and vicinity to nesting grounds;

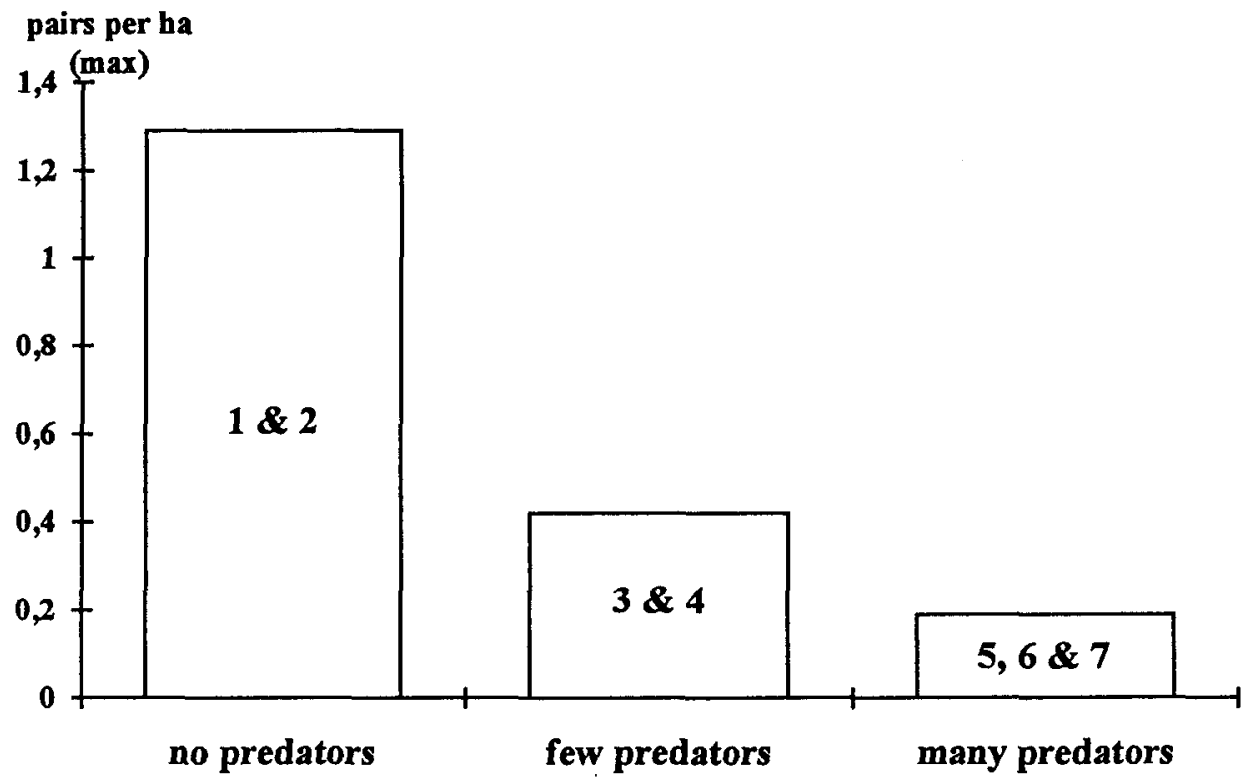

Figure 3. Densities of Malau pairs in study aras 1-7 with different predator impact. 


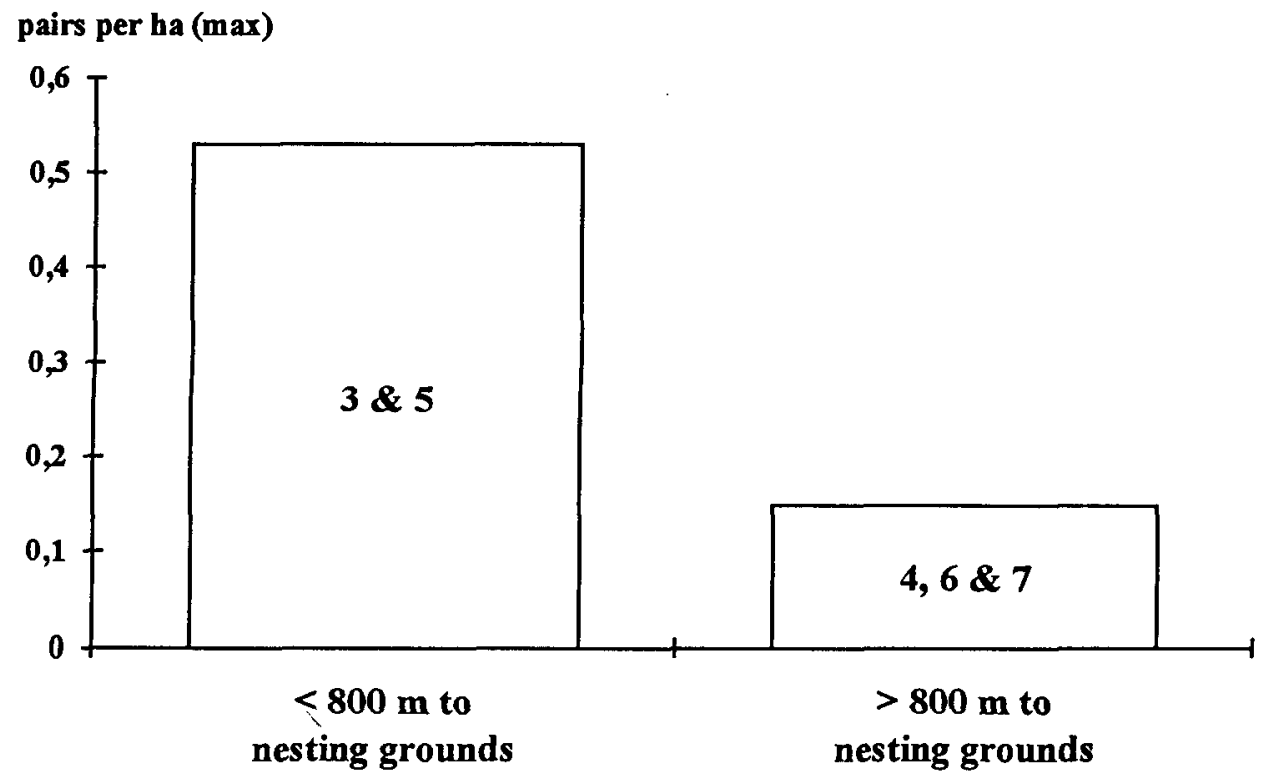

Figure 4. Predator-affected densities of Malau pairs in study areas 3-7 with different distances to the nesting grounds.

Table 2. Density estimates of the Malau on Niuafo'ou

\begin{tabular}{|c|c|c|c|c|c|c|c|c|}
\hline \multirow{2}{*}{$\begin{array}{l}\text { Number of } \\
\text { study area } \\
(\text { Fig. 2) }\end{array}$} & \multirow[b]{2}{*}{ Size (ha) } & \multicolumn{2}{|c|}{$\begin{array}{l}\text { Numbers of } \\
\text { pairs }(n)\end{array}$} & \multirow{2}{*}{$\begin{array}{l}\text { Habitat } \\
\text { type }\end{array}$} & \multicolumn{2}{|c|}{ Pairs per ha } & \multirow{2}{*}{$\begin{array}{l}\text { Total area of } \\
\text { habitat type } \\
\text { (ha) }\end{array}$} & \multirow{2}{*}{$\begin{array}{l}\text { Min. and max. } \\
\text { number of } \\
\text { pairs }\end{array}$} \\
\hline & & $n_{\min }$ & $n_{\max }$ & & $\min$ & $\max$ & & \\
\hline 1 & 11.8 & 12 & 14 & 1 & 1.0 & 1.2 & 40.2 & $40.9-47 \cdot 7$ \\
\hline 2 & 1.4 & 2 & 3 & 2 & 1.4 & 2.1 & 1.4 & $2.0-3.0$ \\
\hline 3 & 8 & 6 & 6 & 3 & 0.8 & 0.8 & $77 \cdot 4$ & 58.1 \\
\hline 4 & 18.2 & 5 & 5 & 4 & 0.3 & 0.3 & 70.2 & $19 \cdot 3$ \\
\hline 5 & 16.5 & 4 & 7 & 5 & 0.2 & 0.4 & 186.1 & $45.1-79.0$ \\
\hline 6 & 23.0 & 2 & 2 & 6 & 0.1 & 0.1 & 266.2 & $22.7-28.3$ \\
\hline 7 & 23.9 & 2 & 3 & 6 & & & & \\
\hline Total & 102.8 & & & & & & 641.5 & $188.1-235.4$ \\
\hline
\end{tabular}

from this a total area for each of the six such categories resulted. The density of the Malau (pairs per ha) in the study areas was then used to calculate the minimum and maximum number of pairs in each category (Table 2), yielding a total reproductive population size of 188-235 pairs.

The status of nesting grounds

Two of the 11 nesting grounds (Lolo and Hikutemotu) studied by Todd (1983) 15 years ago have been abandoned. In Lolo, the only nesting ground in cinder fields on the outer slopes, only one freshly laid egg was found during our stay. Locals confirmed that no eggs were collected there any more. On two nesting grounds (Vai Ahau and Koko) with easy access for people, considerable num- 
bers of burrows were old and overgrown by vegetation. We did not find any nesting grounds additional to those reported by Todd.

\section{Habitat availability}

The Malau inhabited different types of broad-leaved forest in all successional stages, ranging from secondary forest, dominated by coconut palms Cocos nucifera, tavahi trees Rhus taitensis and mango trees Mangifera indica, to mature forest which was not visibly changed by man. In the mature forests trees such as Syzygium clusiaefolium, Diospyros samoensis, Ficus and Sterculia fanaiho grew close together and provided a closed canopy but had only a sparse understorey vegetation. These forests (all types) covered a total area of 719.3 ha (Figure 2), probably more than before the last eruption, though the birds were found to be occupying only 641.5 ha of this habitat.

\section{Discussion}

\section{Density estimates}

In areas where the density was low (all areas except 1 and 2, Figure 2) and therefore well below the carrying capacity, most of the pairs could afford to stay near the nesting grounds. Here the females, which were always observed visiting the nesting grounds alone, had to cover only a short distance to the sites, where they could bury their heavy egg. Additionally they did not have to cross foreign territories where they might have become victims of intraspecific aggression or sexual assaults. On several occasions we observed a female being attacked and chased by a male while approaching a nesting site or digging a burrow.

There are no density figures for megapodes in the literature which can be compared directly with the results we obtained on Niuafo'ou. The most detailed estimate of the megapode population on Niuafo'ou was carried out during a five-month field study in 1979 by Todd (1983), who assessed the total number to be 820 adults, i.e. 410 pairs. Three other estimates were based on less thorough studies. After a short stay on the island in 1969, H. L. Bregulla (verbally 1993) was of the opinion that about 500 megapodes lived there. At the same time Weir (1973), who lived on the island for two years, estimated 2,000 adults and stated that Malau numbers were close to the island's carrying capacity. Rinke's (1991) estimate, based on a 15-day stay on Niuafo'ou, was similar to that of Todd (1983).

\section{Accuracy of the estimate}

Our estimate is based on the number of males that responded to playbacks. In $69 \%(n=98)$ of all cases when males responded, their females were also seen or heard. Nothing can be said about the apparently unaccompanied males because it is still possible that the females were overlooked or just did not react. A more accurate assessment of the number of paired and unpaired males was possible by listening to the megapodes at dusk. During such observation 
periods, lasting 30 to 36 minutes, all pairs were duetting and all single males were calling from their roosting tree, answering each other frequently. Of 29 males heard during this time $89 \%$ were duetting with their female, which was sitting in the same tree or nearby. The proportion of single males in our estimated number should therefore be low and the estimate should represent the number of adult pairs.

Only a few immature birds have to be added to this estimate. This is supported by our experience in trapping the birds on one of the islets in the crater lake, where the traps were set in all Malau territories for an average of two to three weeks within each territory and only one subadult bird out of 20 individuals was caught. Additionally, more than 1,200 hours were spent observing the megapodes on the islet. Chicks and immature birds are inconspicuous and quiet, but, if the population was reproducing well, and assuming that young birds do not move out of high-density areas, we should have seen more than only three chicks and two immature birds (recognizable by their greenish legs and dull plumage). The 14 adult pairs, in contrast, were frequently seen. Feral cats and dogs do not occur on the islet and these predators cannot therefore be responsible for the small numbers of immature birds seen or caught. The proportion of younger age-classes in the population seems to be low, even where predators are absent - and in other parts of Niuafo' ou, where cats and dogs probably do hunt immature birds, this proportion might be even lower. There are no comparable demographic data available in the literature.

\section{Magnitude of decline}

If Todd's (1983) estimate of 820 adult Malaus was accurate, our figure of 188 235 pairs would indicate a decline of approximately $50 \%$ since 1979. However, apart from the fact that playback was used to count the birds in our study, a comparison of these two figures is not fully possible for two other reasons: (1) Todd measured the total area inhabited by the megapodes as 500 ha; although we found that some of the areas described by him had been abandoned, we estimated the occupied area to be 641 ha, perhaps owing to the different methods used for area estimate; (2) Todd calculated the population size from two relatively high densities over an area of 36 ha (Hikutemotu and Motu Molemole); our investigation was based on densities evaluated over 102.8 ha from six different areas. The results thus have to be compared with caution, but a more detailed idea of population development can be gained from a comparison of single areas. On Motu Molemole, an island in the crater lake, with no cats, we found 12-14 pairs, which is similar to Todd's finding of 9-11 pairs. In contrast, only 2-3 pairs remained in Hikutemotu, an area which was occupied by $15-18$ pairs in 1979. Here many cats seemed to live, humans often passed through, and one former nesting ground no longer existed. The megapodes had also disappeared from the forest in the vicinity of the main village where they could be still found in 1979 (Todd 1983).

From interviews with the locals it seemed that when people returned to Niuafo' ou in 1958, after the island had been almost uninhabited for 12 years, the population of the Malau was higher and the birds used more geothermally warm sites for nesting than they do today. These additional sites had been on 
the outer slopes of the island. Weir (1973) also mentioned several nesting grounds on the cinder fields which were facing the sea shore. Nowadays eggs are no longer found there and even in 1979 Todd (1983) failed to find these places. A weakening of volcanic activity does not seem to be responsible for the abandonment of these nesting grounds, as we were still able to find cracks with rising hot air on the old lava fields of the outer slope.

Today the megapodes occur on just 641.5 ha, or $89 \%$ of the area potentially suitable for them ( $719.3 \mathrm{ha}$ ). On only $19 \%$ (119 ha) of the populated area was the density of megapodes above 0.5 pairs per ha. The remaining habitat was only sparsely populated by megapodes, although there was no striking difference in vegetation or food availability between it and that of the more densely populated areas. Assuming a density of 0.5 pairs per ha, a hypothetical 360 pairs could exist on the 719.3 ha of potentially suitable habitat. This would mean that only $52-65 \%$ ( 188 to 235 pairs) of the maximum possible population size remains - or even less, if the true maximum density should be greater than 0.5 pairs per ha.

\section{Causes of decline}

We suggest that egg-collecting is one of the main causes of the declining number of megapodes. The species is protected by law (The Birds and Fish Preservation Act from the Law of Tonga, Act No. 13 of 1934, G 118/31 and 29/33) to the extent that it is forbidden to remove any eggs or birds throughout the year. Nevertheless, at least 50\% of all eggs laid are collected or destroyed by being dug out. At intervals, the eggs on all nesting grounds are harvested, and those sites which are more difficult to reach are not, as suggested by Rinke (1986), spared. Some 10-30 local people dig for eggs regularly, others doing so only from time to time when they come across a nesting ground or when they need eggs for feasts or as gifts for honoured guests. During our stay eggs were even sent by plane to the main island on four occasions. In contrast to former times no local chief today controls or prohibits the collecting of eggs, and the central government, $600 \mathrm{~km}$ to the south, is not able to enforce the law.

People trap and hunt adult megapodes only on a small scale. On one occasion during our visit a hunting party of four men without dogs caught two adult birds, probably females, simply by chasing them.

Nowadays coconut groves are being abandoned owing to the falling price of copra on the world market and very little logging takes place. As Malau will occupy secondary forest, the extent of suitable habitat is clearly not declining. The Melanesian Megapode Megapodius eremita in West New Britain is also found in secondary woodland (Broome et al. 1984).

The failure of the Malau to occupy the whole of the apparently suitable area of 719 ha therefore is probably a result of predation on birds and/or eggcollecting. Cats, which are found all over the island except on the islets in the crater lake, were probably introduced to Niuafo'ou a century ago. Except for one chick killed near a nesting ground, no direct evidence that cats preyed on Malaus was found, whereas Todd (1983) found the remains of seven adults, probably females, killed in succession at one nesting ground. Compared to mound-building megapodes, the Malau's strategy of burrow-nesting seems to 
leave it less vulnerable to predation (Dekker 1989), but the females are susceptible to predation when occupied with digging for up to four hours before egglaying. In the forest, away from the nesting ground, Malaus are shy and look around frequently, so are apparently adapted to ground-living predators to some extent. Feral cats will certainly prey on the Malau, but are unlikely to be the main factor in its decline. Nevertheless, in another megapode, the Australian Brush-turkey Alectura lathami, predation by cats was probably responsible for the high chick mortality of $90-97 \%$ (Jones 1988).

Perhaps feral dogs, which were released mainly when the human population left Niuafo' ou temporarily between 1946 and 1958, also prey upon the Malau, but it is hard to assess the effect of their hunting. Certainly, dogs guided by hunters were successful in killing adults, especially the slower-moving females which carry the heavy egg.

Domestic pigs roam freely in the woods, especially near the villages, and in some woods pigs and Malaus live together, but both species take invertebrates from similar sites and competition may be thus occurring. Pigs were never seen near megapode burrows, however, and do not have any obvious negative influence on the Malau.

It is known from fossil remains in caves that Barn Owls Tyto alba are able to feed on megapodes even bigger than the Malau (Steadman 1993), although we found no evidence of such predation on Niuafo'ou. On one of the islets in the crater lake, none of the 19 ringed Malaus was known to have been preyed on by the abundant Barn Owls over a period of around nine months.

Niuafo'ou is still free from species such as rats Rattus norvegicus and $R$. rattus, which have reached $82 \%$ of the world's major islands (Atkinson 1985). Only the smaller Polynesian rat Rattus exulans is found on Niuafo'ou, but no adverse effect on the Malau is known. It is certainly not able to dig out the eggs. A chick of the Malau, which was raised in an aviary from one day until six weeks old, was not harmed by the many rats that also lived in the cage.

Domestic chickens are confined to the plantations near the villages and are not found in the forests where Malaus occur. Therefore they do not play a role as potential competitors. Only three rails, Banded Rail Gallirallus philippensis, Spotless Crake Porzana tabuensis and Purple Swamphen Porphyrio porphyrio, feed on the forest floor like the Malau, but have presumably always coexisted with it. Also, the overlap in the diets of these species and the Malau is likely to be slight, owing to different foraging behaviour.

\section{Conservation}

The Malau is listed in the Galliform Conservation Assessment Spreadsheet (Garson 1993) as "endangered" but with a stable population. However, our estimate shows a decline, and regular monitoring will be necessary to judge future trends. Conservation measures on Niuafo' ou, such as restrictions on egg-collecting, education of the inhabitants and gazetting of a protected area, especially to include nesting sites, need to be promoted.

Of high priority is the translocation of eggs to another suitable volcanic island in order to establish a second viable population. This translocation is proposed on the basis of the more extended range of megapodes in Polynesia in pre- 
human times (Steadman 1989). Based on the ecological requirements of the birds on Niuafo'ou, which include the availability of geothermal areas for incubation, we screened the island of Late in Tonga for its suitability as reserve for the Malau in a project initiated by the Brehm Fund and supervised by Prof. Dr E. Curio. Late is a semi-dormant volcano of $18.5 \mathrm{~km}^{2}$, which is mainly covered by broad-leaved forest. As an initial trial, we transferred 63 eggs there in September and October 1992. At least nine of these hatched, but the fate of these chicks, and of the other eggs, is not known (Göth and Vogel unpublished data). To establish a healthy population, further eggs need to be brought to this island. Another translocation of eggs was carried out by Rinke (1994) to Fonualei, a low volcanic island about $1.6 \mathrm{~km}$ in diameter, also in Tonga.

\section{Acknowledgements}

The project would not have been possible without the untiring support of Prof. Dr E. Curio, Animal Behaviour Research Group, Ruhr University Bochum, including his cooperation in the field. The Tongan government granted a research permit via the Brehm Fund at Nuku'alofa. Financial support was received from the Dr Otto Röhm Gedächtnisstiftung; Deutsche OrnithologenGesellschaft; Gesellschaft für Tropenornithologie; Vereinigung für Artenschutz, Vogelhaltung und Vogelzucht; WPA International and its German Chapter; Pharm-Allergan $\mathrm{GmbH}$ Vienna; and from the following individuals: Dr K.-P. Erichsen, E. Fromme, the late Dr K. Jungbecker, Dr h. c. A. Müller, M. P. Nicolson, Dr E. Trommsdorff. Local support on Niuafo'ou was given by the families of Falaki Pe'ei, Keneti Kata (all Esia) and Lealiki Lotulelei (Kolofo'ou); on Nuku'alofa by R. Sanft, Consul of the FRG; Burns Philp Ltd, Tonga; P. Havea, Tonga Metereological Service, and Mr Linsey, Ministry of Lands, Survey and Natural Resources, Tonga. D. Arnolds constructed an incubator. H. Grün helped with the technical equipment. $\mathrm{H}$. Schmeiser and his wife Mele provided moral and practical support at critical junctures. R. W. R. J. Dekker read and constructively criticized a first draft of the manuscript. M. Abs, E. Curio and A. Landmann also gave helpful comments on earlier versions of this paper. J. Haas corrected the English. To all these individuals and organizations we are deeply grateful.

\section{References}

Anon. (1991) Population census in the Kingdom of Tonga 1986. Nuku'alofa (Tonga): Statistics Department.

Atkinson, I. A. E. (1985) The spread of commensal species of Rattus to oceanic islands and their effects on island avifaunas. Pp.35-81 in P. J. Moors, ed. Conservation of island birds. Cambridge, U.K.: International Council for Bird Preservation (Techn. Publ. 3).

Broome, L. S., Bishop, K. D. and Anderson, D. R. (1984) Population density and habitat use by Megapodius freycinet eremita in West New Britain. Austral. Wildl. Res. 11: 161171 .

Dekker, R. W. R. J. (1989) Predation and western limits of megapode distribution. J. Biogeogr. 16: 317-321.

Garson, P. J. (1993) Galliform conservation spreadsheet. Megapode Newsl. 7: 6-8. 
Jaggar, T. A. (1931) Geology and geography of Niuafo' ou Volcano. Volcano Letter 318: 1-3. Jones, D. N. (1988) Hatching success of the Australian Brush-turkey in south east Queensland. Emu 88: 260-263.

Richard, J.-J. (1962) Catalogue of the active volcanoes of the world including solfatara fields. Rome: International Association for Volcanology.

Rinke, D. (1986) Notes on the avifauna of Niuafo'ou Island, Kingdom of Tonga. Emu 86: $82-86$.

Rinke, D. (1991) Birds of 'Ata and Late, and additional notes on the avifauna of Niuafo' ou, Kingdom of Tonga. Notornis 38: 131-151.

Rinke, D. (1994) The Malau on Fonualei in northern Tonga. WPA News 44: 7-8.

Rogers, G. (1986) The fire has jumped: eyewitness accounts of the eruption and evacuation of Niuafo'ou, Tonga. Suva (Fiji): Institute of Pacific Studies, University of the South Pacific.

Steadman, D. W. (1989) Extinctions of birds in eastern Polynesia: a review of the record, and comparison with other Pacific Islands. J. Arch. Sci. 16: 177-205.

Steadman, D. W. (1993) Biogeography of Tongan birds before and after human impact. Proc. Natn. Acad. Sci. 90: 818-822.

Todd, D. M. (1983) Pritchard's megapode on Niuafo'ou Island, Kingdom of Tonga. World Pheasant Assoc. J. 8: 69-88.

Weir, D. G. (1973) Status and habits of Megapodius pritchardii. Wilson Bull. 85: 79-82.

\section{ANN GÖTH}

Nockspitzweg 12, 6091 Götzens, Austria.

\section{UWE VOGEL}

Arbeitsgruppe für Verhaltensforschung, Ruhr-Universität Bochum, 44801 Bochum, Germany. 